\title{
MAKING KIN FROM GOLD: Dowry, Gender, and Indian Labor Migration to the Gulf
}

\author{
ANDREA WRIGHT \\ William \& Mary \\ (iD) https:/ / orcid.org/0000-0001-9685-7348
}

I first met Yogesh, a young man from Tamil Nadu, India, in 2009, when he was living in Sharjah, in the United Arab Emirates (UAE). At that time, he was working at a factory that built parts for oil rigs, and I was conducting ethnographic fieldwork on Indian labor migration to the Arabic-speaking countries of the Arabian/Persian Gulf. ${ }^{1}$ Yogesh is one of the millions of men from India who work in the Gulf (MOIA 2013). The reasons for the large numbers of Indians in the Gulf's oil industry include British colonial labor mobilities, the fact that few Gulf nationals work in the industry, and the oil industry's need for workers willing to travel abroad alone to work on fixed-term (usually one- to two-year) projects. Like many of the men with whom I work, Yogesh came from a rural, economically depressed part of India, where his father and two brothers farmed a small plot of land. When Yogesh finished high school, his parents insisted that he take a job through a cousin who also worked in the UAE to pay for his sister's marriage and to contribute to household expenses. Yogesh had been working in the Gulf for about three years when I met him, and he had no plans for moving permanently back to India, although that was what he eventually wished to do.

During the week of Eid al-Adha, Yogesh and his friends allowed me to accompany them as they ran errands and made the most of their vacation time. As 
we traveled through Dubai, our group visited outlet stores and everyone, with the exception of Yogesh, took advantage of the sales and bought clothing, shoes, trinkets, and snacks. Yogesh did not shop with us because he was saving his money for the gold souk. He told me repeatedly that his "primary obligation" was his sister's marriage. To help his sister marry, he told me, he needed to buy gold. This gold would be a gift from his family to his sister's fiancé's family at the time of marriage. While Yogesh did not use the word dowry, anthropologists use the term to describe gifts given by the bride's family to the groom's family at the time of marriage.

It was November when Yogesh and I visited the gold souk, and the weather was hot and humid. Despite the heat, Yogesh did not want to shop for gold in the air-conditioned mall. The stores in the mall were largely empty due to the global financial downturn in 2008, and they were advertising sales on the local television. But the mall felt uncomfortable for Yogesh, because the workforce of the Arabic-speaking Gulf is defined by a racialized labor hierarchy in which South Asian laborers fall near the bottom (Gardner 2010; Vora and Koch 2015). As a result, Indian workers face social discrimination and feel under scrutiny in many public spaces. Yogesh, similar to other Indian working-class men, told me that he perceived patrons and mall employees as unwelcoming. Instead, Yogesh and I ventured into the gold souk in Deira, the historic commercial center of Dubai which houses more than three hundred gold retailers. As we walked, Yogesh looked for a shop with the lowest gold prices. Finally, he decided on a little stall with some design pieces, but mostly ropes of gold. Yogesh was reluctant to spend money on jewelry design as he felt unsure as to what styles his sister preferred, and he did not want to waste money. In the little stall we entered, we heard Tamil, Malayalam, Urdu, and Hindi being spoken by South Asian workers buying gold to take home to their wives, sisters, and mothers. After much deliberation, Yogesh chose a plain chain; its price was determined by weight.

Yogesh expressed worry about the amount of gold that his family asked him to bring home. On his annual trips to India, he spent more than three-quarters of his salary buying gold to accumulate for his sister's dowry. He had wanted to buy his mother some gold, but she instructed him to focus only on getting gold for his sister's wedding. He disliked speaking to his sister on the phone, he told me, because his sister was "mera dimaag ko kha rahi hai," or "eating my brain," by making demands about the quantity of gold she wanted him to buy that seemed impossible for him to meet. Yogesh attempted to satisfy his family's requests by living frugally, which, he told me, included sharing a one-bedroom apartment 
with eight men and refraining from buying unneeded items. He said he felt "phans gaya," stuck or trapped, in the UAE and forced to spend all his money buying gold. An especially large amount of gold was needed because his sister wanted to marry a man who worked in information technology (IT) and lived in Australia. This marriage would allow an upward mobility for his family impossible without his UAE income.

Yogesh felt obliged to provide gold for his sister's dowry, but he also felt he needed to provide money to support his family. After buying gold and paying for his daily needs, Yogesh sent the remainder of his paycheck to his father to use for household expenses. The family Yogesh helped support included not only his sister and his parents but also his brothers, his brothers' wives, and his brothers' children. This type of family organization, called a joint family, is based on the practice of patrilocal social organization and involves a group of adult male joint heirs and these males' dependents living together. Joint families, considered by many Indians to be the ideal family structure, are found among Christians, Muslims, and Hindus throughout India (Lal 2011, 574).

Yogesh is one of the hundreds of workers and their families I have met since 2008 as I have conducted ethnographic research in India and the United Arab Emirates. Most laborers come from rural areas in India. Many poor Indian families see transnational migration as a means of improving their living standards. While historically many Indian migrants were from southern India, today the majority of migrants come from northern Indian states, which are the most reliant on agriculture and have higher unemployment and underemployment rates (MOIA 2013; PLFS 2019, A-141). Most migrants tell me their family farms are smaller than an acre in size and that their job options are either to migrate or to work locally as casual laborers. Casual laborers earn, on average, between USD 2 and USD 3 per day (NSS 2014, A-18-19, 120). In interviews, employees at recruiting agencies, which help companies hire workers for projects outside of India, told me they believe that as an area benefits economically from the inflow of remittances, the education level throughout the community increases and residents of that area are no longer willing to migrate for low-wage, menial labor positions. As a result, companies recruit from agricultural areas in poor states to fill these positions. From the perspective of migrants, I am often told that working in the Gulf pays six to ten times more than a job in India.

Transnational labor migration illuminates how global economic disparities and social inequalities impact individuals and communities (Holmes 2013; Albahari 2015; De León 2015). While economic necessity informs Indian migration 
to the Gulf, migrants indicate that their work abroad is not fully explicable as a simple economic calculus. Indian labor migration to the Gulf may be motivated by gendered kinship obligations; positive attitudes toward migration that raise the status of those who migrate (Ali 2007; Leonard 2007); religious narratives linking the Middle East with a supposedly purer Islam (Hansen 2001); discrimination and violence in India against Muslims, Dalits, and other minorities (Wright 2015); and recruiting processes that may rely on workers' personal networks (Gardner 2012). While social practices and structural inequalities clearly motivate migration, migration also influences social practices. As men purchase gold for their sisters' and daughters' marriages, Indian migrants and their families make sense of labor migration. Migrants and their families are not, and do not see themselves as, passive victims of larger forces. Examining the kinship practices of migrant laborers and historically situating these practices makes clear that capitalism creates "value from non-capitalist value regimes" and depends on "noncapitalist elements" (Tsing 2015, 128,66 ), and that local practices and value systems shape global capitalism (Upadhya 2016). By focusing on kinship obligations and gendered roles within families, this article takes up a case in which kinship motivates migration and migration, in turn, influences kinship practices by providing opportunities to reshape kinship ties and express gendered roles within families.

Gender and kinship are inextricably imbricated: "Kinship is a system of categories" given form by sex and gender relations (Rubin 1975, 169-77), and gender is dynamic, relational, and given context through kinship (Carsten 2004, 75). Sylvia Yanagisako and Jane Collier (1987) argue that when anthropologists focus on procreation and birth in analyzing kinship, they often assume a natural dichotomy between men and women, males and females. Instead, Yanagisako and Collier (1987, 15; emphasis original) call for anthropologists to examine the "the social and cultural processes that cause men and women to appear different from each other." The gift of gold and gold's position as a kinship substance demonstrate how kinship and gender are defined, understood, and enacted within Indian migrant families in the Gulf. An analysis of gold as a kinship substance demonstrates how familial relations and gendered roles shape kinship practices in contexts other than procreation and birth.

This article examines how gold bought by Indian migrants working in the Gulf becomes a kinship substance that maintains family relations and informs gendered labor. To understand the transmogrification of gold from commodity to kinship substance, this article first explores contemporary perceptions of dowry in India and the role of substances in Indian kinship. It then historically situates 
dowries and gendered labor practices and examines the role colonial capitalism and state policies played in shaping kinship practices, illuminating how kinship and economics were, and continue to be, mutually constituting. In the contemporary moment the gift of gold is used to improve a family's status, maintain and shape natal family relations, and fulfill gendered kinship obligations. Often, migrants find that accumulating gold for marriages offers a way to demonstrate they are good sons and brothers, and migrants who do not buy gold for marriages are often viewed negatively by their peers. As sons contribute to their patrilineal joint families, their work abroad is enabled by their wives, who help their husbands fulfill kinship obligations by caring for their husbands' aging parents. As women cook for their in-laws, the food they prepare, like the gold their husbands buy, operates as a kinship substance, but wives often receive little recognition for their kin work. In this context of transnational labor migration, gold provides a way for migrants and their families to shape and maintain kinship relations and fulfill gendered roles within their families.

\section{DOWRY AND INDIAN KINSHIP}

The pressure that Yogesh felt to buy gold for his sister's wedding was not unique to Gulf migrants, despite the fact that dowry is a contested practice. In India, dowry is technically illegal and described regularly in the Indian news as a "social evil." As a result, many families deny giving or asking for dowry, but still engage in large expenditures of gifts from the bride's family to the groom's family, including the gold focused on here. To acquire these gifts, families go to great lengths, including, in extreme cases, selling a kidney (Cohen 2011, 139). Some middle- and upper-class Indians see dowry as a traditional practice that continues despite the 1961 Dowry Prohibition Act, which made it illegal, and many assume the practice will change with modernization (Rahman 2001; Cohen 2002; Lamb 2013). Indians who see dowry as a social evil most often cite its negative impacts on women. These negative impacts are made clear in an amendment to the act in 1984, which strove to offer greater protection to women by explicitly making dowry demands and dowry harassment illegal. In the present, anthropologists have found that dowry contributes to and reinforces Indian preferences for sons, skewed gender demographics, and the higher value placed on male children (Bloch and Rao 2002; Kowalski 2016). In addition, dowry is strongly associated with violence against women, and dowry demands may escalate to domestic violence and murder (Kumar 1993, 116; Oldenburg 2002). Despite these negative impacts, in my conversations with Yogesh and other migrants, I was never told that giving a 
dowry is illegal in India, nor was dowry discussed as a reason for the poor treatment of women. Nonetheless, negative depictions of dowry by Indian newspapers or politicians may have influenced how migrants describe the practice. Notably, migrants did not regularly use the word dowry (nor jahez/dahej in Urdu/Hindi). Rather, men told me they worked in the Gulf to "buy gold for their sisters' (or daughters') marriages" or to "help their sisters marry." In framing their reason for working in the Gulf as "buying gold," they describe buying gold for their sisters and daughters as a practice that connects the natal family and extends those relations as women marry.

When Pandeya, a Hindu from the state of Bihar, narrated his life story to me, he stressed the importance of kinship practices and gendered obligations in his choice to migrate. Pandeya moved to the Gulf in his mid-twenties. He was hired as a manual laborer and, after decades, earned a promotion to a position as a low-level supervisor on an oil project. When I met Pandeya, his parents had passed away, and he, with his wife, Padma, lived in Mumbai, India. In Mumbai, Pandeya had used the connections and skills he had developed in the Gulf to find work at a recruiting agency. Pandeya told me that when he was a young man, his father had farmed a small plot of land, but this land did not produce enough money to support his large family, which included Pandeya, his parents, and his seven sisters. During the first decade that Pandeya worked in the Gulf, he focused on helping provide dowries for his seven sisters. Like many of the men I interviewed, Pandeya felt it was his obligation to help his sisters marry before he did; as a result, Pandeya did not marry until his mid-thirties.

When I asked Pandeya what he provided for his sisters' dowries, he stressed the importance of gold. "In North Indian style of marriage, of course, THE GOLD is an important item for the marriage." As I took notes, Pandeya, who had learnt English while working in the Gulf, looked over my shoulder and offered corrections, insisting that I capitalize "the gold" to indicate its importance. After he was satisfied with my transcription, he continued: "But it is not as important as it's emphasized in South India. Say if it is 50 grams in North, then it would be 500 grams in South Indian marriage. South Indians are more fascinated towards gold. However, one thing is true in all Indians' marriage — i.e., DOWRY — which a girl has to carry to [her] in-laws place." This conversation exemplifies that dowry, also capitalized at Pandeya's direction, is given from a bride's family to the groom's family at marriage. Many Indians consider these gifts to be unidirectional: the bride's family gives a dowry and the groom's family gives no return gifts (Trautmann 1981, 26-27, 277-85). Often, a woman's ties and obligations to her natal family 
are thought to be severed when she, with her dowry, moves to her husband's home (Lamb 2000; Xiang 2005). However, as migrants acquire gold in the Gulf for their daughters' or sisters' marriages, the gift of gold maintains natal family relationships and informs ongoing kinship practices. It is in this sense that I view gold as a kinship substance.

When anthropologists discuss kinship substances, they often focus on bodily substances, such as blood, semen, and breastmilk, and on how these substances are mobilized in the "symbolic constitution of social relations" (Sahlins 2013, 16). In David M. Schneider's (1980) analysis of American folk theories of kinship, kinship is organized by a dichotomy between substance and code of conduct, in which "substance" refers to a naturalized, biologized bond of relatedness represented as blood, or a biogenetic contribution of each parent, whereas relatedness by "code of conduct" is "only" a matter of cultural convention. Subsequent anthropologists have shown how the "seemingly unproblematic distinction" between (fixed) nature and (malleable) culture that underlies the substance/code distinction in American culture obfuscates the interconnectedness of people, socioeconomic practices, and the environment (Feeley-Harnik 1999; Carsten 2004, 114, 2011; Shryock 2013). Kathryn A. Mariner's (2019) recent work on adoption in the United States, for example, demonstrates how materials such as paperwork merge substance and code in American understandings of kinship.

In folk theories of Indian kinship, by contrast, substance and code are more explicitly imbricated in one another since kinship substances are understood as malleable, not biologically determined or fixed. People develop relatedness through intimate interactions, including breastfeeding, sex, and eating, during which organic substances, like breastmilk, semen, and food, are shared (Lamb 2000). Anthropologists approach these organic substances as cultural phenomena that people use to define both the closeness of individual relations and larger social hierarchies (Trawick 1990; Daniel 1996; Busby 1997). Inorganic matter may also be used as a kinship substance, and Indian migrant laborers working in the Gulf draw on gold to reinforce, modify, and extend kinship relations. As men like Pandeya work in the Gulf and use their incomes to purchase gold for their daughters' and/or sisters' marriages, they strengthen natal family ties and fulfill gendered family obligations.

\section{COLONIAL CAPITALISM AND GENDERED LABOR}

Although many Indians tend to regard dowry as traditional, a historic examination of gold and migration reveals how colonial capitalism and state laws have significantly influenced Indian dowry practices, including the central role of 
gold in dowries. During the British colonial period, the enactment of laws, the commodification of labor, and the formation of the market society contributed to shifting social and familial landscapes (Polanyi 1957; Graeber 2009; Mathew 2016). Dowry is one practice impacted as the British colonial government in India altered property rights to more effectively collect taxes. Before the implementation of colonial tax laws, dowry often took the form of immovable assets such as land, and this property was considered women's own (stridhan). As concepts around property changed, dowry increasingly took the form of moveable assets, such as gold. The conversion of property to movable capital allowed for the control of capital to move easily from a woman's father to her husband or parents-in-law, and women no longer held control of this property (Oldenburg 2002, 148). The taxation of dowry and the process of state building influenced how gold as part of the dowry became, over time, a central aspect of contemporary Indian kinship, while appearing to be a fixed and timeless tradition.

Gold's importance relates not only to colonial taxation but also to historic circulations in the Arabian Sea. As Yogesh bought gold and we wandered through the gold souk, he was participating in these circulations. Prior to independence in 1947, India was one of the main exporters of gold in the world. Post-independence, gold smuggling constituted a lucrative endeavor for merchants in the Gulf, as the Indian government charged duties on its import and placed restrictions on its export (Records of the Emirates 1990, 841-46). Gold smuggling continued until the early 1990s, when the liberalization of India's economy included the lifting of both trade restrictions and custom duties (Ali 2010, 16-19). Today, Indian gold merchants in Dubai characterize the city as a "golden frontier" of India. This frontier, like changes to private property, is gendered, and Neha Vora (2013, 92-93) demonstrates that gold merchants celebrate Dubai's "freedoms" that are rooted in "illicit maritime masculine trade."

As gold, colonial officials, and traders circulated through the Arabian Sea, Indian workers also traversed the area. Indian laborers began working at Gulf oil projects in 1908, with the discovery of oil in Persia (today Iran). To protect British oil interests in the Gulf, the British administration, in conjunction with oil companies, re-instituted the system once used to move Indian indentured workers to plantations in the British Empire to move Indian workers to the oilfields (Wright 2021). Throughout the twentieth century, oil companies wanted cheap and easily replaceable labor, and, therefore, the home places of Indians who migrate to the Gulf have expanded. Oil construction projects, in particular, require large numbers of workers who are willing to leave their families for one or two years at a time. 
In the mid-twentieth century, oil projects were the site of political unrest and imperial competition. During the 1960s, strikes by khalījī, or Gulf Arab, workers proved costly, and officials and oil company managers characterized these strikes as threats to both state and corporate security. In response, oil companies decided to preferentially hire South Asian workers, because they believed those workers more loyal to the British. They could also be fired without political or economic consequences (Wright 2020). Today, migrants make up a sizable percentage of the Gulf's population. In Dubai, for example, expatriates comprise about 80 percent of the population, and there are more Indians than any other nationality living in the emirate (Pasha 1999; Leonard 2007; Colton 2010; Castles, de Haas, and Miller 2013).

About 20 percent of the Indian workforce in the UAE are women, usually employed as domestic workers (Prakash, Zachariah, and Rajan 2004, 2229). Domestic work does not pay as well as jobs in the oil industry. In addition, domestic workers in the Gulf, as in much of the world, work unregulated hours and are at higher risk of experiencing physical and verbal abuse (Mahdavi 2011, 126). One key reason uneducated Indian women are unable to find work outside of the domestic sector derives from current emigration restrictions, which build on colonial laws and nationalist discourses. During the colonial period, nationalist and anticolonial writers positioned women's work as ideally located in the home, with an emphasis on the (re)production of future citizens (Rajwade 1938, 83). In nationalist texts, Indian women were discursively situated in the private sphere and valorized for "remain[ing] essentially unwesternized," thereby becoming emblematic of tradition and metonymically representative of the Indian nation (Minault 1982; Chatterjee 1989; Sangari and Vaid 1999; Metcalf 2002). Laws enacted by the postcolonial Indian state reinforced the association between women and the home. After independence, citizenship provisions drew on colonial law and the legal doctrine of coverture to establish citizenship by domicile and birth. Women's citizenship became legally dependent on their fathers' or husbands' domicile and birthplace (Zamindar 2007; Grapevine 2015). The close association of women, the home, and India continues, and Indian women working in the IT industry abroad cultivate a "respectable femininity" that they considered emblematically Indian through their balance of work and home life (Radhakrishnan 2011).

Today, men and women must meet different criteria to emigrate for work. For example, the Emigration Act of 1983 makes it illegal for a woman under thirty years of age to emigrate to work in the Gulf if she has not passed tenth standard in school. Government officials responsible for overseeing the implementation of the 
Emigration Act argue that these restrictions protect the "most vulnerable" Indians from trafficking, as well as safeguarding India's reputation abroad (Wright 2018). As a result, women over thirty who hope to migrate need to obtain a No Objection Certificate, and this certificate must be signed by their husband or father. Furthermore, those who hire maids to work outside of India must be vouched for by an Indian national. Laws restricting women's emigration more than men's, and the discursive location of women's labor within the home, mean that women often rely on their male relatives for their dowries. The gendered exclusion of socially reproductive work from wage labor occurs globally, and scholars have demonstrated the need to attend to "points of gendered contradiction and conflict" as we approach work (Ehrenreich and Russell Hochschild 2002; Weeks 2011; Ahmad 2012, 23, 39-40). By considering how gender, kinship, and labor are historically situated within the expansion of capital as it seeks out new revenues in the form of taxes, commodifies labor, and creates market societies, we are able to see that dowry, something considered traditional in an Indian setting, is actually shaped by liberalization, contemporary statecraft, and transnational migration. Attention to the meaning of gold for dowries and gendered labor highlights these interconnections.

\section{THE GIFT OF DOWRY}

As I began my fieldwork, my understanding of dowry was influenced by my conversations with women's rights advocates in India. I had assumed that in cases like Yogesh's family, because his sister wanted to marry a well-educated young man who lived in Australia, the fiancé's family would not ask for a dowry. Yet contrary to my expectations, migration and increased participation in transnational, neoliberal economies do not decrease the practice of giving a dowry, but, rather, have the reverse effect. Although most men do not explicitly use the term dowry and instead use phrases such as "buying gold to help their sisters marry", all migrants stressed that their sisters and/or daughters need to take gold with them when they move to their in-laws' homes. Ramchandra, a lower-caste farmer's son from Uttar Pradesh, began working in the Gulf when he was twenty years old after "dropping out of school" and spending years unable to find work in India. In the Gulf, he said, he could "find" more money_ money needed because he had "two sisters and no money in India." As he explained, "helping his sisters marry" was his "first responsibility." When I asked Ramchandra what was needed for his sisters to marry, he was shocked that I would not know. After staring for a moment, Ramchandra said, simply, "gold.” Like other migrants with whom I spoke, Ramchandra was involved neither in negotiating his sisters' marriages nor in deciding what other gifts 
his sisters would bring to their in-laws' houses. These arrangements, Ramchandra and others told me, are done by family members in India and, as migrants in the Gulf, their duty is to buy gold for these marriages.

Now, Ramchandra's sisters are married, and he sends money for his father to build a pucca house, or a house made of concrete and bricks, an expense often taken on by a family before a son's marriage to ensure a "good match." ${ }^{3}$ While Ramchandra married before he began building his family's pucca house, other migrants told me they were building such houses in preparation for their own marriages. Building a pucca house, they said, would help their parents find them "good" wives. When I asked what makes a woman a good wife, migrants often described a woman's ability to look after or care for the home, children, and parents; a woman's religious piety; and a wife's family's economic status. Men never discussed with me the amount of dowry they anticipated their wives would bring, and, if I tried to ask, they told me that their parents arrange such matters.

Nonetheless, anthropological studies of Indian transnational migration suggest that this type of migration drives increasingly large dowries. Men working in IT, in particular, have seen the largest increase in the amount of dowry they are able to obtain from a bride's family, in part due to their potential to migrate to Australia, the United Kingdom, or the United States for work (van der Veer 2005, 278). Xiang Biao's (2005, 370; 2011, 33, 36) work on Indian IT workers in Australia demonstrates that men feel compelled to give as much dowry as possible for their daughters' or sisters' marriages to maintain their families' status and free their families from the "burden" of the daughter. Xiang (2005, 369) approaches dowry as an institution, and this approach makes clear how dowry is informed by an economic calculation and its close relationship to other social institutions, such as education. ${ }^{4}$ In Xiang's and other anthropological studies, the importance of dowry is considered within the context of marriage and building relationships between families. In contrast, examining how men acquire gold for their daughters' and sisters' marriages demonstrates how gold operates within the natal family as both gift and kinship substance. The value of this gift exceeds its financial value, and migrants and their families represent dowry as a gift that maintains and recreates kinship ties and gendered roles.

\section{The Value of Gold}

Shabana, an Indian Muslim woman from Tamil Nadu, described to me the multiple values dowry holds for a family. Shabana's husband, brother, and father work in the Gulf, and she lives with her two sons and her husband's parents. While 
much of her day revolves around caring for her children and in-laws and overseeing the household's daily tasks, Shabana also maintains close ties to her natal family and regularly visits her sisters and mother. In the summer of 2011, Shabana and I chatted frequently, and most of our conversations included a discussion of gold's price. At that time, the U.S. and European stock markets were volatile, and the price of gold was consistently increasing. While I had known Shabana since 2009, we had never before discussed the price of gold. Her new interest, Shabana explained, came from her younger sister Asma's marriage preparations. One day, in a conversation with her friends, Shabana asked, "Why is gold increasing at a skyrocketing pace? What has gold rates to do with U.S. dollar or oil? Or is there no gold in the gold mines?" Sighing, she said that the increased prices "make people's life more miserable than it already is." Shabana's friends commiserated with her and offered their perspectives on the gold market. One friend explained that gold is expensive because "people don't trust any commodity but gold; shares on the stock market are rubbish." Another friend made the case that Indians played a direct role in gold's price, saying, "Maybe if Mallus [Malayalam speakers from the state of Kerala] and Gujjus [people from the state of Gujarat] stop buying so much it will probably drop." Another friend also commented on this link between Indian wedding practices and gold's price, with the conjecture that gold was so expensive because "more and more Mallus are getting married." Both Kerala and Gujarat are Indian states known for their trading and have a visible presence in the Gulf, often as middle- and upper-class workers. The (joking) assumption in the conversation was that the wealthy from these Indian states were getting married in higher numbers and therefore driving up the price of gold.

In Shabana's conversation with her friends, gold was explicitly discussed as a commodity, with its market price a concern. As many anthropologists have demonstrated, the value of a commodity is not rooted in what an individual will pay for that particular commodity. Rather, the value is a "momentary instantiation of coagulation out of an open, dynamic, and interactive process" involving alienation, wage labor, and historical context (Pedersen 2013, 19; see also, e.g., Coronil 1997; Graeber 2001, 31-32). While the price of gold certainly held importance to Shabana, as we continued to discuss Asma's dowry, it became clear that giving gold for a dowry was valued for its expression of kinship ties as well as its economic value. Colonial capitalism played a key role in gold's emergence as a central component of dowry. In addition, Indian migrants and their families often note that gold bought in the Gulf is purer than gold bought in India (even if this does not empirically hold true) and that they see gold as an item that retains its value 
over time. As Shabana describes below, she believes Indians trust gold more than money, because money fluctuates in value according to the global markets, but gold's value remains stable. It is this stability and purity that contributes to gold's importance in Indian kinship.

When discussing gold's importance for Asma's dowry, Shabana described gold as a gift that situates one's family within a community, maintains relationships, and expresses care. She told me that her family felt "compelled" to supply a large amount of gold for Asma's dowry because her family worked in the Gulf. Through providing a large dowry of gold for Asma's wedding, the family was attempting to assert its relatively new class position. This position was further improved by Asma's marriage, like Yogesh's sister's, to an Indian IT worker who lived in Australia. For both Shabana and Yogesh, gold's value went beyond demonstrating their families' wealth. Rather, they saw gold bought in the Gulf and given for dowries as a way to uplift women's natal families. This uplift becomes possible because gold operates as a kinship substance that maintains ties with female kin, as seen in changing gift practices.

In a later conversation with Shabana and Asma, Shabana told me her husband was contributing "a handful" of gold for Asma's wedding. Because this movement of goods from a husband to his wife's family differed from descriptions of gifts moving only from the wife's family to the husband's family, I asked if this contribution was related to Shabana's mahr, or the gift given from the groom to the bride in Muslim marriage (nikah). Asma dismissed my question and explained, "Dowries are very important in India. For Muslims, the rich are expected to give a house, gold, and a car. The poor are only expected to give a car and gold.” In contrast, Asma told me, mahr, the groom's gift to the bride, is a "menial amount. Poor Indian Muslim grooms only give INR 100 (USD 2 in 2011) and the rich give AED 100 (approximately INR 1,400 or USD 27 in 2011).” As our conversation continued, Asma clarified that mahr constitutes a religious obligation and that, as a self-described devout Muslim, she expected only a small gift from her husband. In contrast, there is no religious obligation for a dowry, and the gold her fiancé's family expected at the wedding was substantial and openly negotiated. To clarify why gold for Asma's marriage was so important and why her husband was contributing to help Asma marry, Shabana explained that her husband's actions were both "practical" and a way to ensure Asma's happiness. Asma's marriage to an IT worker living in Australia, Shabana told me, would mean that both Shabana's natal family and her husband's family would "rise in status." Simultaneously, the family would be caring for Asma by ensuring her husband was a "good match." 


\section{Masculinity, Labor, and Gold}

To understand how gold transmogrifies into a kinship substance, we must think about the value of dowry not in economic terms, but as a gift. Sareeta Amrute (2016, 166-70), in her study of skilled Indian migrants in Germany, argues that gifts function as one of the means by which Indian middle-class workers abroad represent their work to their families and build communities. In the case of Nepalese migration, Ina Zharkevich (2019) demonstrates that money is particularly useful at expressing and maintaining kinship ties in a context in which sharing food or having other regular contact is absent. Following the work of Marilyn Strathern $(1988,143,286)$ in Melanesia, anthropologists often argue that the value of the gift is located in social relationships of reciprocal exchange, whereas David Graeber $(2001,45)$ extends Nancy D. Munn's $(1986,127)$ examination of gifts to argue that value emerges in action, including how people represent the importance of their gift giving to themselves. Importantly, migrants and their families understand buying gold for dowries as representative of masculinity and familial obligation.

As men migrate to work in the Gulf, they extend not only the reach but also the geographic scope of their kinship networks. Indian migrants maintain and restructure kinship relations by sending remittances and purchasing gold for their sisters' dowries. Examining how migrants represent these gifts provides insight into how people make migration and labor meaningful in ways additional to labor's economic value. Anna Lowenhaupt Tsing (2015, 121-28) argues that commodities become gifts through a process of translation - a process in which mediators confer on certain commodities "relation-making powers." This process of translation becomes necessary because of alienation, which Tsing $(2015,121)$ defines as how things (including labor) are made commodities by being "torn from life worlds." Labor alienates people from the product of their labor, their work, themselves, and their community. The kinship practices of Indian migrants and their families complicate understandings of alienation as rupture, as migrant labor works simultaneously in multiple value systems.

Migrants navigate tensions between commodities and gifts through representing the gift of gold as indicative of gendered labor and gendered obligations. For Indian migrants, bestowing gifts of gold to their sisters and remittances to their fathers demonstrates that they are "men" within their families and communities. Established by fulfilling roles as good brothers and sons, this masculinity provides an alternative to hegemonic representations of adult masculinity in India that are predicated on marriage. In many poor farming communities in India, young 
men cannot get married because of increasing unemployment and lack of opportunities (Chowdhry 2005). In the face of high unemployment, northern Indian families may allocate resources to prioritize a son's employment or marriage at the expense of a daughter's marriage (Jeffrey 2010, 177-78). Transnational migration, on the other hand, provides routes through which men may express adult masculinity by being dutiful brothers and sons.

In 2010, I met often with Ramchandra and his colleagues during their lunch breaks as they worked to build an oil rig in Abu Dhabi. One day, I ate lunch with a dozen men and, as we talked, they described how they regularly sent money home, as well as purchased gold for their female relatives' weddings. During the lunch, Ramchandra introduced me to Mohammed, a young Muslim man from northern India, who was new to this crew. When he introduced us, Ramchandra said, "voh achchha beta hai," or "he [Mohammed] is a good son." Mohammed responded in English, telling me, "I [am] supporting fully to family" by sending all of his paycheck home, because "[I am] fully devoted to family." While some workers send money monthly, others told me they send money "every five months because it is a more substantial amount and avoids fees." Workers generally send money using UAE Exchange, a popular wire-transfer service. Migrants buy gold in the souk and then wear it home as chains around their necks to avoid import duties. While they differed in how often they sent money home, my lunch companions agreed that sending this money and taking home gold was their farz or karm, the Urdu and Hindi words, respectively, for "duty." By fulfilling this duty, they told me, a man demonstrates he is a good son and dutiful brother.

During lunch, one man told me that doing one's duty and working in the Gulf may also lead to a migrant's family "giving [the migrant] more respect." This respect manifested in their opinions being sought on topics ranging from family conflicts to household purchases to children's education. Ramchandra, worried that I would not understand, turned to me and told me that working in the Gulf "elevated him" in the eyes of his family. This, he said, was due not only to his financial contributions but also because no one else in his family had flown on a plane or traveled far from home. To demonstrate his "elevated” status, Ramchandra described how his family had called him the week before to ask his advice before buying a piece of farm equipment. As we talked, my lunch companions described their work as integral to their families, as the household's relationships and interactions extended from rural villages in India to construction sites in the Gulf.

Despite agreeing on the importance of sending money and buying gold for dowries, my lunch companions did not agree on what percentage of their pay- 
check they needed to give to their families. As lunch continued, Ramchandra and Sunil, a Hindu also from northern India, became embroiled in a heated debate over this question. Ramchandra had been working in the Gulf intermittently for more than a decade, and he had recently started listening to a radio show in which the host (an Indian living in the UAE) encouraged listeners to save their money instead of sending it home. The show resonated with Ramchandra, and he had recently opened a personal savings account that no one in his family could access. The reason, Ramchandra said, was because "whatever you send, they [your family] upgrade the needs" - meaning that families would spend all the money migrants earned on both necessary and unnecessary items, and ask for increasingly larger amounts of money. This meant, Ramchandra told us, that if a migrant did not build his own savings, "when you go back, [you] will have nothing." He continued by telling us that, of course, personal saving needed to be weighed against family needs. While the show's host recommended that migrants save for themselves at least 50 percent of their income, Ramchandra said he sent home 60 percent, keeping the remaining 40 percent. Ramchandra's discussion of personal savings upset Sunil, and he dismissed the radio show. Loudly, Sunil argued for sending the entirety of one's paycheck to one's family, except the money used to buy gold for weddings or minutes for a mobile phone. He felt that sending money was a son's duty. To enforce his point, Sunil quoted the Bhagavad Gita, a Hindu religious text: "karm karo fal ki chinta na karo," a phrase that could mean either "do your duty and don't expect a reward" or "do your duty and don't worry about the outcome." Sunil used this phrase to stress the importance of actions in fulfilling one's familial duties. For Sunil, the issue resided in the question of how he could be a good son or brother, not how his family might spend the money. Refusing to speculate as to what may happen in the future, Sunil stressed that the importance of the gift (either money or dowry) lay in the act of giving.

\section{The Danger of Forgetting One's Family}

While my lunch companions and other migrants, like Yogesh, all sent money and bought gold for dowries, the families of migrants often express concern that they will be forgotten after a man moves abroad. As in many contexts, transnational migration has the potential to destabilize families and disrupt gendered roles within them (Dahinden 2005; Gamburd 2008; Coe 2011a). This holds particularly true when migrants' access to cash provides an opportunity for them to express masculinity outside of their families (Osella and Osella 2000). In 2009, I sat in a recruiting agency in Mumbai, India, with Pandeya and other employees as 
the agency held interviews for oil projects in the Gulf. As employees collected resumés, a group of young men who had recently returned from working in the Gulf arrived. They wore large gold watches, button-up shirts made of shiny, iridescent material, and trendy new sports shoes. Their fashion choices set them apart from the dozens of men already standing in the office building's hallways and courtyard, all of whom were dressed simply and without accessories. When this group of men walked in, the recruiting agency employees with whom I sat immediately began talking about them. Based on their appearance, the agency employees said that these young men had clearly not spent their Gulf money wisely and had "forgotten" their families. The agency employees quickly reached consensus that these young men had been "seduced by Dubai ki chamak [the glitter of Dubai]." Chamak, a Hindi term meaning "shiny," may describe the shininess of modern and new things, such as Dubai's high-rises or shopping malls. Indian laborers in the UAE often use chamak to refer, derogatorily, to men who wear name-brand clothes or dress stylishly. It may also be used to describe Indians trying to present themselves as Arabs. As all of the employees with whom I sat had previously worked in the Gulf, their choice of chamak gestured toward the allure of Dubai's modernity, a recognition of the Gulf's racialized hierarchies, and a criticism of these young men's consumption choices.

The seductive nature of the Gulf and the possibility that men might spend money on unneeded luxury goods came up regularly in conversations at the agency. One agency employee, Jimmy, told me he lectured "noobies," or first-time emigrants, on the best way to spend money. ${ }^{5}$ He explained, "noobies [have] totally funny ideas, and they don't know that they are making tax-free money and they should be doing things like buying gold. They are going to earn and save - not to spend." When I asked how common this was, Jimmy replied, "People think they are in the Gulf and they can spend, but then the workers return to India with nothing." According to Jimmy, the Gulf's place in popular imagination contributed to young men's choices to consume luxury goods and not support their families. "People have certain habits that they need to support. They also want to buy good clothes because they think 'I am in the Gulf, so I can spend money, and I need nice clothes and to get fat to show that [I was] in the Gulf." Jimmy and his colleagues believed that when young migrants returned from the Gulf wearing "flashy" new clothes and other ostentatious displays of wealth, what they were exhibiting was their failure to fulfill kinship obligations and care for their families. 


\section{WOMEN'S WORK AND MIGRATION}

Workers who did not forget their families often discussed their families' importance in facilitating migration. Amit, an older man who had worked as a manual laborer in the Gulf for more than twenty years, focused primarily on his family when I asked him why he was once again moving to the Gulf for work. He said,

I am going only for work. My family needs the money. You can find jobs in India, but they don't pay as well. I will compromise to whatever . . . I have to, because I am sacrificing to go to make money for my family. So, I will adjust, just like my family will need to adjust, because I am not at home.

As we talked, Amit described his family, which included his wife and children, as well as his mother, brothers, brothers' wives, and his brothers' children. Amit understood that both he and his family were sacrificing in order to send him to the Gulf. His family sacrificed by missing his presence in the household, but also by initially borrowing large amounts of money from a moneylender to facilitate Amit's migration. Amit's story demonstrates a common one in which joint families and shared responsibilities both motivate and facilitate migration.

As Amit described, living in joint families provides support for migration, and men, like Ramchandra, often say they receive greater respect from their families after going abroad. Gendered obligations influence this choice to migrate as well. Women's work, meanwhile, often supports men's migration to the Gulf. Yet this work often remains unrecognized, and many wives do not feel they receive the same respect that their husbands do (cf. Bhatt 2018). Migrants repeatedly told me that their wives care for their parents while they are in the Gulf, and migrants see this care - conducted on their behalf - as one of their duties as sons. Many women, however, find it hard to live in their in-laws' homes without their husbands. Pandeya's wife, Padma, told me she found it challenging to live with her in-laws when her husband was away because, she said, her mother-in-law treated her as a servant and demanded that she do all the household chores. She also told me Pandeya's sisters would regularly visit their parents and then berate her for not properly caring for their parents. According to Padma, without Pandeya present, she was "alone" living with Pandeya's parents, without anyone to care for her. Padma's description of being “alone” while living with Pandeya's parents points to the importance of a husband in building a relationship between a wife and her in-laws.

When Pandeya worked in the Gulf, Padma said she wanted to live abroad with him, rather than live "only" with her in-laws. Despite her wishes, Padma 
never traveled to the Gulf, in part because Gulf governments place restrictions that make it challenging for lower-wage employees to bring dependents. Yet even if it had been legally possible, Padma told me, Pandeya would never have agreed for her to leave his family. At a later date, this topic came up when I spoke to Pandeya, and he told me it was hard to live apart from his wife, but that it was his duty (karm) as a son to care for or look after (dekhbāl karna) his parents. Padma fulfilled this duty on his behalf by living with his parents. In this context of patrilocal social organization, neither Padma nor Pandeya argued that Padma had a responsibility to look after her own family. Rather, after marriage, Padma's duty became to care for Pandeya and to help her husband fulfill his obligations to his family. During the time Padma lived with Pandeya's parents, she cared for them by cooking food, and this food shaped and informed Padma's relationship with both her husband and her in-laws. As wives cook for their parents-in-law, they enable the generation of additional kinship substances, including gold and money. It is a wife's care of her husband's aging parents that facilitates migration, a migration on which the Gulf's oil industry depends.

\section{FROM COMMODITY TO KINSHIP SUBSTANCE}

Although we often understand money and love to form connections between people in different, noncomplementary, ways, this distinction does not resonate globally. In many contexts, money is used to express intimacy and care. As Cati Coe's (2011b) work in Ghana demonstrates, children of migrants see the money from their parents as expressions of intimacy. In the case of Nepalese migrants, Zharkevich (2019) shows that remittances constitute a substance of relatedness that helps span the distance created by transnational migration. For Indian migrants to the Gulf, gold, too, has an economic value within families, and the gift of gold is seen as an expression of care. Unlike monetary remittances, however, the semiotic materiality of gold means that, within the context of kinship, gold not only economically uplifts a family but also constitutes a gift that operates as a kinship substance (cf. Munn 1986; Keane 2003; Fehérváry 2012). While food and other kinship substances inform relatedness through proximity and daily interactions, gold bought in the Gulf transcends geographic distance. It manages to do so because of its role as a gift that connects people, a gift perceived as pure because it is bought in the Gulf. Gold, as a kinship substance, also calls into question distinctions made between substance and code, fixity and malleability. Like blood, gold is seen as durable, in contrast to cash, which fluctuates with the markets. Gold is also seen as malleable, as the plain ropes of gold bought by migrants such as Yogesh 
are often reshaped by their recipients. Here, gold's qualities as pure, stable, and malleable are mutually constituted with its role as a gift that builds and maintains kinship relations and indexes one's gender.

As they buy gold for their sisters' and daughters' dowries, migrants navigate gold as a gift and a fulfillment of gendered kinship obligations. Men often feel their status within their households improve as a result. Their gift of gold reinforces the fixity of relations by maintaining connections within natal families; simultaneously, gold informs a malleability of relations by extending broader kinship networks. Women, meanwhile, actively support the migration of their husbands and brothers through their own labor, although this work often goes unacknowledged. The femininity of migrants' wives becomes reinforced by their role in helping fulfill their husbands' duties of care. These dynamic interactions of kinship and gender shape and are shaped by migratory movements and economic practices.

In the case of Indian migrant labor to the Gulf, kinship practices and economic necessity are deeply intertwined. The Gulf's oil industry depends on Indian kinship relations to have access to the large numbers of temporary workers required by oil projects. In turn, migrants use money earned in the oil industry to provide financial support to their families, to purchase gold for their sisters' or daughters' marriages, and for possible further migration. Gold, a key component of dowry, becomes a kinship substance that continues natal family ties after men's transnational migration and their sisters' subsequent marriages. Migrants represent giving gold as the fulfillment of their gendered kinship obligations as sons and brothers. Exploring this gift of gold as historically and culturally situated illuminates how it forms part of contemporary kin-making, how gold is imbricated in economic transformations and class relations, and how gold becomes a gendered kinship substance as salient as semen, blood, or breastmilk.

\begin{abstract}
Drawing on ethnographic research in the United Arab Emirates and India, this article explores relationships among Indian kinship, gender, and transnational migration through a focus on gold that migrant men buy for their sisters' or daughters' weddings. Gold, used as a key component of dowry, is often considered "traditional" in an Indian setting, but is actually shaped by liberalization, contemporary statecraft, and transnational migration. As migrants purchase gold for their sisters and daughters with money they earn in the Gulf, they express adult masculinity by being dutiful brothers and sons. This examination of Indian labor migration reveals how workers and their families understand migration as a way to build and maintain kinship ties, and how gold bought in the Gulf becomes a kinship substance that informs
\end{abstract}


understandings of gender and family. [kinship, gifts, labor, gender, migration, masculinity]

\section{शोध-सार}

संयुक्त अरब अमीरात और भारत में किये हुए मानव-जाति संबंधी शोध के बिना पर यह शोध-पत्र भारतीय रिश्तेदारी, लिंग, और अंतरराष्ट्रीय प्रवास के संबंध का अध्ययन करता है, जिसका केंद्र वह सोना है जो प्रवासी पुरुष अपनी बहन-बेटियों के विवाह के लिए ख़रीदते हैं। सोना, जो कि दहेज का महत्वपूर्ण अंग है, अक्सर भारतीय समाज में एक “प्रथा" की तरह समझा जाता है। मगर इसका मतलब वास्तव में उदारीकरण, समकालीन शासनकाल, और अंतरराष्ट्रीय प्रवास से प्रभावित है। प्रवासी अपनी बहन-बेटियों के लिए खाड़ी देशों से कमाए पैसों से जब सोना ख़रीदते हैं तो वे कर्तव्य पालन करके अपना पुरुषत्व दिखाते हैं। भारतीय प्रवासी श्रमिकों का यह अध्ययन इस बात को दर्शाता है कि कामगार और उनके परिवारवाले इसे रिश्तेढ़ारी बनाने और निभाने का एक तरीक़ा समझते हैं, और इस तरह खाड़ी का सोना एक रिश्तेढारी की वस्तु बन जाता है जो लिंग और परिवार के मतलब पर रोशनी डालता है। [रिश्तेदारी, उपहार, श्रमिक, लिंग, प्रवास, पुरुषत्व]

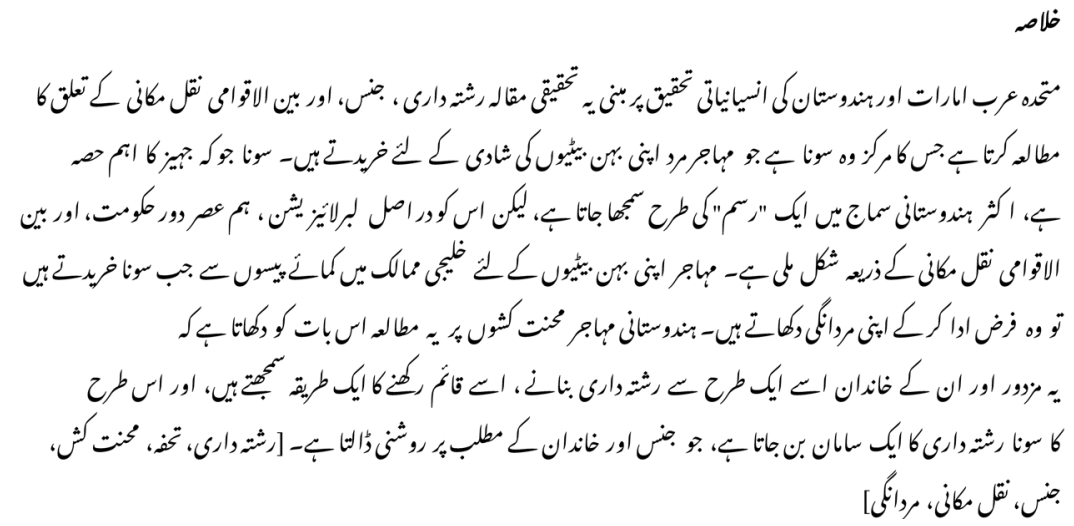

\section{NOTES}

Acknowledgments I owe a great deal to the people in India and the UAE with whom I work. I am particularly indebted to Pandeya, who tragically passed away while I was working on this article and whom I still miss. During the time I knew Pandeya, he always welcomed my questions and answered them with great patience and thoughtfulness. Critical and insightful feedback from the anonymous reviewers at Cultural Anthropology and Heather Paxon's generous engagement greatly strengthened this article. I thank Syed Ali, David Boyk, and Jimmy for their help and feedback on language translation. This article has greatly benefited from conversations with and feedback by Hoda Bandeh-Ahmadi, Alexandre Belieav, David Boyk, David William Cohen, Juan R. Cole, William Fisher, Matthew Hull, Elizabeth Kelly, Julia Kowalski, Michelle Lelievre, Purvi Mehta, and Farina Mir. Funding from the Fulbright Hays Doctoral Dissertation Research Award, the Joint Program in Anthropology \& History at the University of Michigan, and William \& Mary helped make research for this article possible.

1. Given the controversy regarding the name of the Arabian/Persian Gulf, I use the Gulf throughout this essay. 
2. In Yogesh's home, he primarily speaks Tamil, but he is also fluent in Hindustani, and the latter is the language we use in conversations.

3. In India, a pucca house is contrasted with a katcha house, or one made of mud, thatch, or other low-quality materials. The preference is for a pucca house.

4. In Gift of the Virgin, Lina Fruzzetti (1982) focuses on the tension between the sacred gift of a father giving a daughter to a husband's household and the economic gift of dowry. In this and other research on dowry, the focus is on the relationships between the father and daughter and the father and his daughter's husband's family at the time of marriage.

5. Noobies is a common Indian-English slang word for what we call "rookies" in the United States. During my research, noobie was often used interchangeably with kaccha limbu, a Marathi phrase that literally means "unripe lemons."

\section{REFERENCES}

Ahmad, Attiya

2012 "Beyond Labor: Foreign Residents in the Persian Gulf States." In Migrant Labor in the Persian Gulf, edited by Mehran Kamrava and Zahra Babar, 21-40. New York: Columbia University Press.

Albahari, Maurizio

2015 Crimes of Peace: Mediterranean Migrations at the World's Deadliest Border. Philadelphia: University of Pennsylvania Press.

Ali, Syed

2007 “'Go West Young Man': The Culture of Migration among Muslims in Hyderabad, India." Journal of Ethnic and Migration Studies 33, no. 1: 37-58. http://doi. org/10.1080/13691830601043489.

2010 Dubai: Gilded Cage. New Haven, Conn.: Yale University Press. Amrute, Sareeta

2016 Encoding Race, Encoding Class: Indian IT Workers in Berlin. Durham, N.C.: Duke University Press.

Bhatt, Amy

2018 High-Tech Housewives: Indian IT Workers, Gendered Labor, and Transmigration. Seattle: University of Washington Press.

Bloch, Francis, and Vijayendra Rao

2002 "Terror as a Bargaining Instrument: A Case Study of Dowry Violence in Rural India." American Economic Review 92, no. 4: 1029-43. https://doi. Busby, Cecilia org/10.1257/00028280260344588.

1997 "Of Marriage and Marriageability: Gender and Dravidian Kinship." Journal of the Carsten, Janet Royal Anthropological Institute 3, no. 1: 21-42. https://doi.org/10.2307/3034363.

2004 After Kinship. Cambridge, UK: Cambridge University Press.

2011 "Substance and Relationality: Blood in Contexts." Annual Review of Anthropology 40: 19-35. https://doi.org/10.1146/annurev.anthro.012809.105000.

Castles, Stephen, Hein de Haas, and Mark J. Miller

2013 The Age of Migration: International Population Movements in the Modern World. 5th ed. London: Palgrave Macmillan.

Chatterjee, Partha

1989 “The Nationalist Resolution of the Women's Question.” In Recasting Women: Essays in Indian Colonial History, edited by Kumkum Sangari and Sudesh Vaid, 233-53.

Chowdhry, Prem New Delhi: Kali for Women.

2005 "Crisis of Masculinity in Haryana." Economic and Political Weekly 40, no. 49: 518998. https://www.epw.in/journal/2005/49/special-articles/crisis-masculinityharyana.html. 
Coe, Cati

2011a "What Is the Impact of Transnational Migration on Family Life? Women's Comparisons of Internal and International Migration in a Small Town in Ghana." American Ethnologist 38, no. 1: 148-63. https://doi.org/10.1111/j.15481425.2010.01298.x.

2011b "What Is Love? The Materiality of Care in Ghanaian Transnational Families." International Migration 49, no. 6: 7-24.

Cohen, Lawrence

2002 No Aging in India: Alzheimer's, the Bad Family, and Other Modern Things. New Delhi: Oxford University Press.

2011 "Migrant Supplementarity: Remaking Biological Relatedness in Chinese Military and Indian Five-Star Hospitals." Body and Society 17, nos. 2-3: 31-54. https://doi.

Colton, Nora Ann org/10.1177\%2F1357034X11400766.

2010 “The International Political Economy of Gulf Migration.” Middle East Institute Viewpoints, February 2. https://www.mei.edu/publications/international-politicaleconomy-gulf-migration.

Coronil, Fernando

1997 The Magical State: Nature, Money, and Modernity in Venezuela. Chicago: University of Chicago Press.

Dahinden, Janine

2005 "Contesting Transnationalism? Lessons from the Study of Albanian Migration Networks from Former Yugoslavia.” Global Networks 5, no. 2: 191-208. https:// doi.org/10.1111/j.1471-0374.2005.00114.x.

Daniel, E. Valentine

1996 Charred Lullabies: Chapters in an Anthropology of Violence. Princeton, N.J.: Princeton University Press.

De León, Jason

2015 The Land of Open Graves: Living and Dying on the Migrant Trail. Photographs by Michael Wells. Oakland: University of California Press.

Ehrenreich, Barbara, and Arlie Russell Hochschild, eds.

2002 Global Woman: Nannies, Maids, and Sex Workers in the New Economy. New York: Henry Holt.

Feeley-Harnik, Gillian

1999 “'Communities of Blood': The Natural History of Kinship in Nineteenth-Century America." Comparative Studies in Society and History 41, no. 2: 215-62. https://doi. org/10.1017/S0010417599002078.

Fehérváry, Krisztina

2012 "From Socialist Modern to Super-Natural Organicism: Cosmological Transformations through Home Decor.” Cultural Anthropology 27, no. 4: 615-40.

Fruzzetti, Lina https://doi.org/10.1111/j.1548-1360.2012.01164.x.

1982 The Gift of a Virgin: Women, Marriage, and Ritual in Bengali Society. New Brunswick, Gamburd, Michele R. N.J.: Rutgers University Press.

2008 "Milk Teeth and Jet Planes: Kin Relations in Families of Sri Lanka's Transnational Domestic Servants." City and Society 20, no. 1: 5-31. https://doi.org/10.1111/ Gardner, Andrew M. j.1548-744X.2008.00003.x.

2010 City of Strangers: Gulf Migration and the Indian Community in Bahrain. Ithaca, N.Y.: Cornell University Press.

2012 “Why Do They Keep Coming? Labor Migrants in the Gulf States." In Migrant Labor in the Persian Gulf, edited by Mehran Kamrava and Zahra Babar, 41-58. New York: Columbia University Press. 
Graeber, David

2001 Toward an Anthropological Theory of Value: The False Coin of Our Own Dreams. New York: Palgrave.

2009 “Debt, Violence, and Impersonal Markets: Polanyian Meditations.” In Market and Society: The Great Transformation, edited by Chris Hann and Keith Hart, 106-32.

Grapevine, Rebecca Cambridge, UK: Cambridge University Press.

2015 "Family Matters: Citizenship and Marriage in India, 1939-72." PhD diss., University of Michigan.

Hansen, Thomas Blom

2001 "Bridging the Gulf: Migration, Modernity and Identity among Muslims in Mumbai." In Community, Empire and Migration: South Asians in Diaspora, edited by Holmes, Seth M. Crispin Bates, 261-85. New York: Palgrave Macmillan.

2013 Fresh Fruit, Broken Bodies: Migrant Farmworkers in the United States. Berkeley: University of California Press.

Jeffrey, Craig

2010 Timepass: Youth, Class, and the Politics of Waiting in India. Stanford, Calif.: Stanford University Press.

Keane, Webb

2003 "Semiotics and the Social Analysis of Material Things." Language and Communication 23, nos. 3-4: 409-25. https://doi.org/10.1016/S0271-5309(03)00010-7.

Kowalski, Julia

2016 "Ordering Dependence: Care, Disorder, and Kinship Ideology in North Indian Antiviolence Counseling.” American Ethnologist 43, no. 1: 63-75. https://doi.org/ 10.1111/amet.12263.

Kumar, Radha

1993 The History of Doing: An Illustrated Account of Movements for Women's Rights and Feminism in India, 1800-1990. New Delhi: Kali for Women.

Lal, Jayati

2011 “(Un)becoming Women: Indian Factory Women's Counternarratives of Gender." Sociological Review 59, no. 3: 553-78. https://doi.org/10.1111\%2Fj.1467954X.2011.02026.x.

Lamb, Sarah

2000 White Saris and Sweet Mangoes: Aging, Gender, and Body in North India. Berkeley: University of California Press.

2013 "In/dependence, Intergenerational Uncertainty, and the Ambivalent State: Perceptions of Old Age Security in India.” Journal of South Asian Studies 36, no. 1: 65-78. https://doi.org/10.1080/00856401.2012.732552.

Leonard, Karen Isaksen

2007 Locating Home: India's Hyderabadis Abroad. Stanford, Calif.: Stanford University Press.

Mahdavi, Pardis

2011 Gridlock: Labor, Migration, and Human Trafficking in Dubai. Stanford, Calif.: Stanford University Press.

Mariner, Kathryn A.

2019 “'Who you are in these pieces of paper': Imagining Future Kinship through Auto/ Biographical Adoption Documents in the United States." Cultural Anthropology 34, Mathew, Johan no. 4: 529-54. https://doi.org/10.14506/ca34.4.03.

2016 Margins of the Market: Trafficking and Capitalism across the Arabian Sea. Oakland, Calif.: University of California Press.

Metcalf, Barbara D.

2002 Islamic Revival in British India: Deoband, 1860-1900. New Delhi: Oxford University Press. 
Minault, Gail

1982 The Khilafat Movement: Religious Symbolism and Political Mobilization in India. New York: Columbia University Press.

MOIA (Ministry of Overseas Indian Affairs)

2013 “Annual Report 2012-13.” New Delhi: Government of India.

Munn, Nancy D.

1986 The Fame of Gawa: A Symbolic Study of Value Transformation in a Massim (Papua New Guinea) Society. Durham, N.C.: Duke University Press.

NSS (National Sample Survey Office)

2014 "Employment and Unemployment Situation in India." NSS Report No. 554(68/10/1). New Delhi: Ministry of Statistics and Programme Implementation, Government of India.

Oldenburg, Veena Talwar

2002 Dowry Murder: The Imperial Origins of a Cultural Crime. Oxford, UK: Oxford University Press.

Osella, Filippo, and Caroline Osella

2000 "Migration, Money and Masculinity in Kerala." Journal of the Royal Anthropological Institute 6, no. 1: 117-33. https://doi.org/10.1111/1467-9655.t01-1-00007.

Pasha, A. K.

1999 Perspectives on India and the Gulf States. New Delhi: Détente Publications.

Pedersen, David

2013 American Value: Migrants, Money, and Meaning in El Salvador and the United States. Chicago: University of Chicago Press.

PLFS (Periodic Labour Force Survey)

2019 Annual Report: Periodic Labour Force Survey (PLFS) (June 2017-June 2018). New Delhi: Ministry of Statistics and Programme Implementation, National Statistical Office, Government of India.

Polanyi, Karl

1957 The Great Transformation: The Political and Economic Origins of Our Time. Boston: Beacon Press. Originally published in 1944.

Prakash, B. A., K. C. Zachariah, and S. Irudaya Rajan

2004 "Indian Workers in UAE." Economic and Political Weekly 39, no. 22: 2227-34. https://www.epw.in/journal/2004/22/review-labour-review-issues-specials/ indian-workers-uae.html.

Radhakrishnan, Smitha

2011 Appropriately Indian: Gender and Culture in a New Transnational Class. Durham, N.C.: Duke University Press.

Rahman, Anisur

2001 Indian Labour Migration to the Gulf: A Socio-economic Analysis. New Delhi: Rajat Publications.

Rajwade, L.

1938 "The Indian Mother and Her Problems." In Our Cause: A Symposium by Indian Women, edited by Shyam Kumari Nehru, 73-89. Allahabad: Kitabistan.

Records of the Emirates

1990 Letter from HBM Political Agency, Trucial States, Dubai, to Sir William Luce, British Residency, Bahrain. January 19, 1966. 1181/66C. Cambridge: Cambridge Archival Editions.

Rubin, Gayle

1975 “The Traffic in Women: Notes on the 'Political Economy' of Sex." In Toward an Anthropology of Women, edited by Rayner R. Reiter, 157-210. New York: Monthly

Sahlins, Marshall Review Press.

2013 What Kinship Is - And Is Not. Chicago: University of Chicago Press. 
Sangari, Kumkum, and Sudesh Vaid

1999 "Recasting Women: An Introduction." In Recasting Women: Essays in Colonial History, edited by Kumkum Sangari and Sudesh Vaid, 1-26. New Delhi: Kali for

Schneider, David M. Women. Originally published in 1989.

1980 American Kinship: A Cultural Account. 2nd ed. Chicago: University of Chicago Press. Shryock, Andrew

2013 “It's This, Not That: How Marshall Sahlins Solves Kinship." Hau 3, no. 2: 271-79. https://doi.org/10.14318/hau3.2.016.

Strathern, Marilyn

1988 The Gender of the Gift: Problems with Women and Problems with Society in Melanesia. Berkeley: University of California Press.

Trautmann, Thomas R.

1981 Dravidian Kinship. New York: Cambridge University Press.

Trawick, Margaret

1990 Notes on Love in a Tamil Family. Berkeley: University of California Press.

Tsing, Anna Lowenhaupt

2015 The Mushroom at the End of the World. Princeton, N.J.: Princeton University Press. Upadhya, Carol

2016 Reengineering India: Work, Capital, and Class in an Offshore Economy. Oxford: Oxford University Press.

van der Veer, Peter

2005 "Virtual India: Indian IT Labor and the Nation-State." In Sovereign Bodies: Citizens, Migrants, and States in the Postcolonial World, edited by Thomas Blom Hansen and Finn Stepputat, 276-90. Princeton, N.J.: Princeton University Press.

Vora, Neha

2013 Impossible Citizens: Dubai's Indian Diaspora. Durham, N.C.: Duke University Press. Vora, Neha, and Natalie Koch

2015 "Everyday Inclusions: Rethinking Ethnocracy, Kafala, and Belonging in the Arabian Peninsula." Studies in Ethnicity and Nationalism 15, no. 3: 540-52. https:// doi.org/10.1111/sena.12158.

Weeks, Kathi

2011 The Problem with Work: Feminism, Marxism, Antiwork Politics, and Postwork Imaginaries. Durham, N.C.: Duke University Press.

Wright, Andrea

2015 "Migratory Pipelines: Labor and Oil in the Arabian Sea." PhD diss., University of Michigan.

2018 “The Immoral Traffic in Women': Regulating Indian Emigration to the Persian Gulf." In Borders and Mobility in South Asia and Beyond, edited by Reece Jones and Md. Azmeary Ferdoush. Amsterdam: Amsterdam University Press.

2020 "Imperial Labor: Strikes, Security, and the Depoliticization of Oil Production." In Indigenous, Immigrant, and Indentured in South Asia: A Globalized Modern History, edited by Neilesh Bose. New York: Bloomsbury.

2021 "From Slaves to Contract Workers: Genealogies of Consent and Security in Indian Labor Migration.” Journal of World History 32, no. 1.

Xiang Biao

2005 "Gender, Dowry and the Migration System of Indian Information Technology Professionals." Indian Journal of Gender Studies 12, nos. 2-3: 357-80. https://doi.or $\mathrm{g} / 10.1177 \% 2 \mathrm{~F} 097152150501200209$.

2011 Global "Body Shopping": An Indian Labor System in the Information Technology Industry. Princeton, N.J.: Princeton University Press.

Yanagisako, Sylvia Junko, and Jane Fishburne Collier

1987 "Toward a Unified Analysis of Gender and Kinship." In Gender and Kinship: Essays Toward a Unified Analysis, edited by Jane Fishburne Collier and Sylvia Junko Yanagisako. Stanford, Calif.: Stanford University Press. 
Zamindar, Vazira Fazila-Yacoobali

2007 The Long Partition and the Making of Modern South Asia: Refugees, Boundaries, Histories. New York: Columbia University Press.

Zharkevich, Ina

2019 "Money and Blood: Remittances as a Substance of Relatedness in Transnational Families in Nepal." American Anthropologist 121, no. 4: 884-96. https://doi. $\operatorname{org} / 10.1111 / a m a n .13316$. 